\title{
PENGEMBANGAN PERANGKAT PEMBELAJARAN MODEL DEBAT AKTIF PADA MATERI PEMANASAN GLOBAL UNTUK SISWA KELAS XI SMA
}

\author{
Okta Ariesan Deka, Nirwana, Nyoman Rohadi \\ Program Studi Pendidikan Fisika FKIP-UNIB \\ Jl. WR. Supratman Kandang Limun Bengkulu \\ Email: oktaariesan23@gmail.com
}

\begin{abstract}
ABSTRAK
Berdasarkan hasil obesrvasi yang dilakukan disekolah, perangkat pembelajaran yang digunakan guru belum tersusun dengan baik dan belum menggunakan instrumen penilaian yang sesuai dengan model pembelajran yang digunakan. Penelitian ini bertujuan untuk menghasilkan perangkat pembelajaran model debat aktif pada materi pemanasan global untuk kelas XI SMA. Penelitian ini menggunakan metode penelitian research and development dengan model Sugiyono Level 1. Adapun tahapan-tahapan yaitu potensi dan masalah, studi literatur dan pengumpulan informasi, desain produk, validasi desain dan perbaikan desain. Validasi produk dilakukan oleh 3 ahli yang ditinjau dari 3 aspek yaitu aspek penyajian, aspek isi dan aspek kebahasaan. Berdasarkan hasil uji validasi aspek penyajian didapatkan persentase sebesar 75,5\% dengan kategori valid, aspek isi didapatkan persentase sebesar 81,6\% dengan kategori sangat valid, aspek kebahasaan didapatkan persentase sebesar 83,3\% dengan kategori sangat valid. Berdasarkan hasil tersebut, dapat disimpulkan bahwa perangkat pembelajaran model debat aktif pada materi pemanasan global untuk kelas XI SMA yang dihasilkan sudah valid/layak untuk diujicobakan dengan persentase rata-rata sebesar 80,13\%.
\end{abstract}

Kata kunci : Perangkat Pembelajaran, Debat Aktif, Berpikir Kritis, Berargumentasi

\begin{abstract}
Based on the results of observation carried out in school, the learning tools used by teachers were not well structured and did not use assessment instruments that are in accordance with the learning model used. This study aimd to produced an active debate model of learning tools on the subject of global warming for high school class XI. This research used research and development method with Sugiyono Level 1 model. The stages were potential and problems, literature study and information gathering, product design, design validation and design improvement. Product validation was carried out by 3 experts reviewed from 3 aspects namely presentation, content and linguistic aspects. Based on the results of the validation test of the presentation aspect obtained a percentage of $75.5 \%$ with a valid category, the content aspect obtained a percentage of $81.6 \%$ with a very valid category, the linguistic aspect obtained a percentage of $83.3 \%$ with a very valid category. Based on these results, it can be concluded that the active debate model of learning tools on the matter of global warming for high school class XI produced is valid / feasible to be tested with an average percentage of $80.13 \%$.
\end{abstract}

Keywords : Learning Tools, Active Debate, Critical Thinking, Arguing

\section{PENDAHULUAN}

Perkembangan dunia pendidikan saat ini tidak hanya terlepas dari fasilitas pendidikan yang semakin memadai terutama pada sekolah-sekolah yang sudah maju dalam menyediakan sarana dan prasarana sekolah, tetapi juga berkembang melalui kualitas tenaga pendidik yang memiliki pengetahuan dan keterampilan dalam kerja yang inovatif, kreatif dan efisien sehingga proses pembelajaran dapat lebih menarik dan dapat meningkatkan kemampuan siswa agar dapat berperan aktif dalam proses pembelajaran. Pemerintah telah menetapkan tentang Standar Proses pada Bab IIIA bagian 3 huruf c yang berbunyi "Berpusat pada peserta didik untuk mendorong semangat belajar, motivasi, minat, kreativitas, inisiatif, inspirasi, inovasi dan kemandirian" (Bettelheim 1980). Berdasarkan ketetapan ini, siswa ditempatkan sebagai sentral sehingga perbedaan karakteristik siswa harus digunakan sebagai salah satu perancangan dalam menentukan pembelajaran. Pembelajaran yang baik adalah pembelajaran dimana siswa mampu membangun konsepnya sendiri secara aktif pada setiap proses pembelajaran di kelas. Pembelajaran yang aktif ini guru dituntut agar mampu kreatif dalam mengelola pembelajaran dan menyesuaikan kecocokan antara model pembelajaran yang digunakan serta materi yang diajarkan agar dapat mencapai tujuan pembelajaran secara optimal(Dan et al. 2014). 
Proses pembelajaran yang baik adalah pembelajaran yang mampu mengembangkan kemampuan yang dibutuhkan dalam abad 21 yaitu kemampuan berpikir kritis, memecahkan masalah, berkolaborasi, dan berkomunikasi (Nurdyansyah and Fahyuni 2016). Untuk mencapai pembelajaran yang baik ini, siswa perlu dilatih dalam berkomunikasi dalam pembelajaran. Pada suatu pembelajaran dapat berhasil melelui pembentukan komunikasi yang efektif pada setiap komponen belajar. Adapun komponen belajar itu sendiri yaitu tujuan pendidikan pembelajaran, peserta didik atau siswa, tenaga kependidikan atau guru perencanaan pembelajaran, strategi atau metode pembelajaran, media pembelajaran, dan evaluasi pembelajaran. Dari beberapa komponen tersebut model pembelajaran yang sesuai dengan materi pembelajaran dapat menjadi salah satu cara untuk membentuk komunikasi yang efektif (Herayanti, Fuaddunnazmi, and Habibi 2017).

Perangkat pembelajaran lain yang diamati adalah bahan ajar fisika yang digunakan, bahan ajar tersebut ternyata juga tidak sesuai denga karakteristik siswa (Diani 2015). Siswa tidak mungkin memiliki semua buku yang beredar dipasaran karena jumlahnya yang terlalu banyak dan harganya yang relatif mahal. Sementara itu, dari segi lembar penilaian yang digunakan guru, terlihat bahwa indikator kompetensi siswa tidak sesuai dengan penilaian yang digunakan guru, sehingga penilaian yang dilakukan belum maksimal. Dari pengamatan perangkat pembelajaran yang digunakan ini, dapat disimpulkan bahwa perangkat pembelajaran yang digunakan dalam pembelajaran belum bisa mendukung terciptanya aktivitas, kompetensi, dan karakter siswa yang lebih baik.

Hasil penelitian menunjukkan bahwa ada pengaruh interaksi yang signifikan antar pembelajaran debat dan kemampuan berpikir kritis mahasiswa yang mana sangat berperan dalam meningkatkan hasil belajar siswa (Zahara et al. 2019). Hasil penelitian lain mendiskripsikan bahwa terdapat peningkatan hasil kemampuan berpikir kritis siswa setelah diberi treatment pembelajaran menggunakan metode debat ((Tata Sutabri 2011). Berdasarkan literatur diatas dapat menjadi pedoman arah dari penelitian ini, bahwasannya melalui model pembelajaran debat terdapat pengaruh yang signifikan dalam peningkatan kemampuan berpikir kritis siswa.

Kemampuan berargumentasi siswa masih rendah. Hal ini dibuktikan dengan siswa masih mengalami kesulitan dalam mengungkapkan ide/gagasan, kemampuan bertanya masih rendah, dan siswa mengalami kesulitan dalam memecahkan masalah pembelajaran (Fauziyah 2019). Untuk itu perlu dilakukan suatu inovasi dalam pembelajaran agar siswa tidak mengalami kesulitan dalam mengemukakan gagasan. Selanjutnya kemampuan berargumentasi siswa yang belum optimal dikarenakan proses pembelajaran yang dikembangkan lebih banyak menekankan pada pemberian materi dibandingkan memotivasi siswa dalam mengemukakan pendapat yang berkaitan dengan materi (Firdauzi, Widiantie, and Handayani 2019). Materi yang diajarkan pada penelitian ini adalah pemanasan global karena rata-rata guru mata pelajaran di sekolah ini tidak terlalu menekankan pentingnya materi ini dijelaskan secara efektif kepada siswa sehingga siswa kurang termotivasi untuk mendalami materi ini. Guru biasanya menggunakan metode caramah, penugasan dan persentasi kelompok di dalam kelas. Hal ini kurang sejalan dengan tuntutan kurikulum 2013 yang sangat menekankan optimalnya aspek peran siswa dalam belajar. Materi ini dirasa sangat perlu diinovasi agar dapat diserap dengan siswa dan diterapkan dalam kehidupan sehari-hari. Supaya tercapai apa yang menjadi tujuan pembelajaran pada materi ini perlu digunakan model pembelajaran yang sesuai agar dapat lebih relevan dengan kondisi saat ini.

Pada saat magang 2 dilakukan observasi lapangan, ditemukan bahwa proses pembelajaran di kelas XI IPA SMAN 7 Kota Bengkulu masih didominasi oleh guru dan siswa kurang dapat berkembang secara mandiri melalui penemuan dan proses berpikirnya, siswa hanya diam dan tidak berani memberikan argumentasinya terhadap materi yang diberikan. Siswa hanya mendengarkan saja apa yang disampaikan oleh guru tanpa mengetahui makna dari materi yang disampaikan. Hal ini terjadi karena proses pembelajaran yang tidak menarik dan membosankan. Selain itu dilihat dari adanya siswa yang mengantuk dan ribut di kelas menyebabkan proes pembelajaran menjadi kurang efektif dan akbiatnya siswa tidak bisa memahami sebagian materi yang diberikan oleh guru. Hal ini dibuktikan pada saat siswa ditanya kembali apa yang sudah dijelaskan oleh guru, sebagian besar siswa bisa menjawab pertanyaan yang dilontarkan oleh guru. Masalah ini tentu bisa mengakibatkan daya serap siswa menurun dan bisa juga berdampak pada prestasi belajar siswa. Oleh karena itu, 
perlu adanya perangkat pembelajaran yang sesuai dalam meningkatkan kemampuan berpikir kritis dan berargumentasi siswa dalam proses pembelajaran. Salah satu model pembelajaran yang tepat yaitu model Debat Aktif. Model ini diharapkan bisa membuat siswa mampu untuk berpikir kritis akan isi-isu lingkungan yang terkait dengan materi ini. Karena situasi saat ini isi-isu lingkungan perlu diangkat didalam pemahaman siswa agar bisa diterapkan dalam kehidupan sehari-hari dan siswa dapat menerapkan pola pikir yang berkaitan dengan keberlangsungan kehidupan anak cucu mereka nanti.

Berdasarkan hasil wawancara kegiatan pembelajaran dengan guru mata pelajaran fisika yang dilakukan di SMAN 7 Kota Bengkulu pada bulan November 2019 diketahui bahwa proses pembelajaran fisika di kelas XI IPA pada materi pemanasan global ini masih menggunakan model pembelajaran yang kurang menarik dan siswa masih kurang dalam pemahaman dan penerapan materi ini dalam kehidupan sehari-hari. Kemudian perangkat pembelajarannya pun belum tersusun dengan baik misalnya kelengkapan bahan ajar yang masih kurang, instrumen penelitian yang digunakan belum sesuai dengan model dan hasil yang ingin diukurpun tidak sejalan dengan apa yang menjadi tuntutan kurikulum saat ini. Untuk itu perlu adanya pengembangan perangkat pembelajaran yang sesuai dengan materi ini agar dapat mencapai tujuan pembelajaran yang optimal, maka peneliti mengangkat judul " Pengembangan Perangkat Pembelajaran Model Debat Aktif Pada Materi Pemanasan Global untuk Siswa Kelas XI SMA" Adapun rumusan masalah dalam penelitian ini adalah (1) Bagaimana proses pembuatan perangkat pembelajaran model debat aktif pada materi pemanasan global untuk siswa kelas XI SMA ?. (2) Bagaimana kalayakan perangkat pembelajaran model debat aktif pada materi pemanasan global untuk siswa kelas XI SMA ?

\section{METODE PENELITIAN}

Penelitian ini menggunakan metode R\&D. Metode R\&D (Research and Development) adalah metode penelitian yang digunakan untuk menghasilkan produk tertentu dan menguji keefektifan produk tersebut (Centre 2005). Metode yang digunakan R\&D tipe rancangan level 1 (meneliti tanpa menguji coba). Penelitian yang dilakukan hanya menghasilkan rancangan produk dan rancangan tersebut divalidasi secara internal (pendapat ahli dan praktisi) tetapi tidak diproduksi atau diuji secara eksternal (pengujian lapangan) (Yoki 2010). Penelitian ini menghasilkan perangkat pembelajaran model debat aktif pada materi pemanasan global untuk berargumentasi siswa kelas XI SMA. Untuk mendapatkan perangkat pembelajaran tersebut menggunakan metode penelitian research and develompent dengan tipe rancangan level 1.

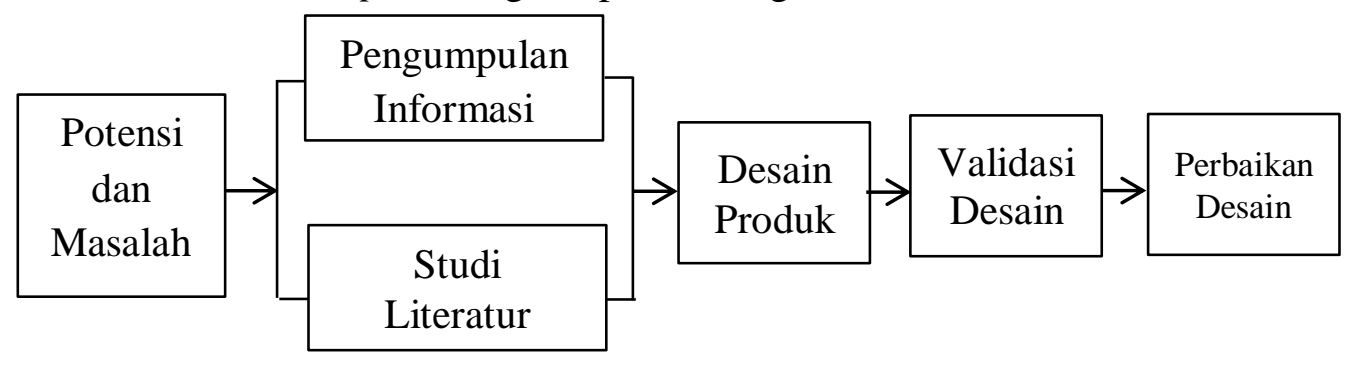

Gambar. 1 Langkah-Langkah Penelitian

Langkah pertama yaitu mencari potensi dan masalah dengan studi literatur dan pengumpulan informasi, selanjutnya membuat desain produk yang kemudian produk tersebut divalidasi. Hasil validasi produk tersebut di perbaiki menurut saran dari validator.

\subsection{Rancangan Produk}

Untuk mendesain produk berupa perangkat pembelajaran model debat aktif pada materi pemanasan global untuk siswa kelas XI SMA dilakukan dengan tahapan yaitu mendesain materi dan mendesain RPP. Penyusunan materi Perangkat pembelajaran diawali dengan silabus, dan kompetensi dasar. Berdasarkan silabus, kompetensi dasar pada materi pemanasan global yaitu : (3.12) Menganalisis gejala pemanasan global dan dampaknya bagi kehidupan dan lingkungan; (4.12) Menyajikan ide / gagasan pemecahan masalah gejala pemanasan global, dan dampaknya bagi kehidupan dan lingkungan. 


\subsection{Desain Produk}

Berdasarkan kekurangan yang ditemukan maka dikembangkanlah perangkat pembelajaran model debat Aktif Pada Materi Pemanasan Global Untuk Siswa Kelas XI SMA Diawali Dengan Merancang Cover Dan Kata Pengantar, Kemudian Membuat Daftar Isi yang akan mempermudah pencarian. Selanjutnya membuat rancangan RPP berdasarkan silabus yang sudah ada dan dibuat juga lembar debat siswa sebagai pedoman siswa dalam berdebat dikelas. Untuk mengukur kemampuan siswa maka dibuatlah instrumen tes beserta rubrik rubrik penilaian agar kemampuan siswa dapat dinilai dengan baik. Lalu dibuatlah daftar pustaka agar sumber yang diambil oleh perangkat pembelajaran ini jelas. Kunci jawaban dan materi ajar dibuat untuk lebih mempermudah guru dan siswa dalam menggunakan perangkat pembelajaran ini.

2.3 Rumus Matematika

1. Menentukan Persentase Nilai Validasi

$$
\text { Persentase }(\mathrm{P})=\frac{\text { skor total }}{\text { Total skor ideal skor maksimal }} \times 100 \%
$$

2. Menentukan Rata-Rata Hasil Validasi

$$
R=\frac{\sum_{i=1}^{N} v_{i}}{N}
$$

Dimana, $\mathrm{R}$ adalah Rerata hasil penilaian dari validator, $\mathrm{V}_{\mathrm{i}}$ adalah Rerata skor hasil penilaian validator ke-i, dan N adalah Banyak validator (Purwono, Yutmini, and Anitah 2014)

Tabel 1.Interpretasi Skor

\begin{tabular}{cc}
\hline Persentase & Interpretasi \\
\hline $80 \%-100 \%$ & Sangat layak/ Sangat baik/ Sangat setuju/ Sangat valid \\
$66 \%-79 \%$ & Layak/ Baik/ Setuju/ Valid \\
$56 \%-65 \%$ & Kurang layak/ Kurang baik/ Kurang setuju/ Kurang valid \\
$0 \%-55 \%$ & Tidak layak/ Tidak baik/ Tidak setuju/ Tidak valid \\
\hline
\end{tabular}

Tabel 1. Interpretasi Skor digunakan untuk mengetahui seberapa valid desain perangkat pembelajaran jika dihubungkan dengan hasil persentase perhitungan nilai angket dari validator. (Chodijah, Fauzi, and Wulan 2012)

\section{HASIL DAN PEMBAHASAN}

\subsection{Hasil}

Uji validitas aspek penyajian terdiri dari 3 butir penilaian yang harus terpenuhi. Berdasarkan uji validitas aspek penyajian, aspek isi dan aspek kebahasaan yang dilakukan oleh judgement ahli, hasil akhir rata-rata uji validitas dapat dilihat pada tabel 2 dibawah ini :

Tabel 2. Hasil Akhir Uji Validitas

\begin{tabular}{ccc}
\hline Aspek & Nilai Rata-Rata & Kategori \\
\hline Penyajian & $75,5 \%$ & Valid \\
Isi & $81,6 \%$ & Sangat Valid \\
Kebahasaan & $83,3 \%$ & Sangat Valid \\
\hline Rata-Rata & $\mathbf{8 0 , 1 3 \%}$ & Sangat Valid
\end{tabular}

Tabel 2. Adalah hasil akhir nilai rata-rata keseluruhan dari aspek-aspek yang dinilai.

\subsection{Pembahasan}

Penelitian ini bertujuan untuk mengembangkan perangkat pembelajaran model debat aktif pada materi pemanasan global untuk siswa kelas XI SMA yang valid, untuk megembangkan produk ini digunakan langkah-langkah penelitian $R \& D$ dengan tipe rancangan level 1, yaitu potensi dan masalah, studi literatur dan pengumpulan informasi, desain produk, validasi desain, dan perbaikan desain/desain teruji.

Langkah pertama yang dilakukan adalah mengidentifikasi potensi dan masalah. Pada penelitian ini, untuk mengidentifikasi potensi dan masalah dilakukan dengan observasi di SMAN 7 kota Bengkulu (Lampiran 1). Potensi yang ditemukan yaitu di sekolah tersebut telah menerapkan kurikukum 2013, dimana pada kurikulum 2013 lebih menuntut siswa untuk aktif selama proses 
pembelajaran, sehingga guru harus menciptakan suasana belajar yang dapat membuat siswa melakukan aktivitas dan saling berinteraksi selama proses pembelajaran, salah satunya yaitu dengan berdebat. Kegiatan debat membutuhkan langkah-langkah yang sesuai dengan RPP maka digunakanlah model pembelajaran debat aktif pada perangkat pembelajaran ini kemudian siswa juga membutuhkan lembar debat siswa sebagai panduan pembahasan dalam mengaitkan permasalahan dengan materi pembelajaran.

Selama proses observasi ditemukan masalah yaitu sekolah tersebut belum menggunakan perangkat pembelajaran yang dapat melatih kemampuan berpikir kritis dan berargumentasi serta siswa kurang antusias atau tertarik dalam mengikuti pembelajaran fisika, dikarenakan proses pembelajaran yang membosankan yaitu mereka hanya mendengar penjelasan materi dari guru. Setelah ditemukan masalah selanjutnya dilakukan studi literatur dan pengumpulan informasi.

Studi literatur dilakukan untuk mengumpulkan pendukung pengembangan produk. Oleh karena produk yang dikembangkan adalah perangkat pembelajaran model debat aktif pada materi pemanasan global untuk siswa kelas XI SMA, maka berdasarkan hasil studi literatur dengan diterapkannya kurikulum 2013 maka diharapkan adanya peningkatan kualitas siswa salah satunya dilakukan oleh guru yang berfokus pada peningkatan kualitas pembelajaran di kelas dengan cara melibatkan siswa secara aktif dalam proses pembelajaran. Seorang pendidik dapat membekali siswa agar memperoleh keterampilan hidup (life skill) seperti berkomunikasi, berani mengemukakan pendapat, berani berargumen serta mampu mempertanggung jawabkan apa yang ia ucapkan melalui perangkat pembelajaran. Bisa dikatakan bahwa perangkat pembelajaran dapat dikembangkan sebagai media untuk belajar aktif dan dapat mengarahkan peserta didik memecahkan persoalan fisika melalui langkah-langkah debat dalam pemecahan masalah. Berdasarkan penelitian yang relevan dapat disimpulkan bahwa perangkat pembelajaran model debat aktif pada materi pemanasan global untuk siswa kelas XI SMA dapat dikembangkan sebagai bahan belajar siswa dan dapat membuat siswa lebih aktif dalam proses pembelajaran.

Selanjutnya untuk mendukung studi literatur maka dilakukan pengumpulan informasi. Pengumpulan informasi pada penelitian ini menggunakan lembar pengumpulan informasi melalui jurnal, buku, dan internet untuk mengetahui penelitian yang menunjang pada penelitian dan pengembangan. Berdasarkan penelitian (Diani 2015) yang berjudul "Pengembangan Perangkat Pembelajaran Fisika Berbasis Pendidikan Karakter dengan Model Problem Based Intsruction" menyatakan bahwa hasil pengembangan dan hasil uji coba yang dilkakukan, dapat disimpulkan bahwa hasil validasi dari para validator menunjukkan bahwa perangkat pembelajaran fisika berbasis pendidikan karakter dengan model problem based intsruction sangat valid, sangat praktis, dan sangat efektif. Efektivitas perangkat ditunjukkan pula dengan adanya peningkatan aktivitas dan hasil belajar siswa.

Langkah selanjutnya dalam penelitian ini adalah mendesain produk. Langkah ini sudah memasuki tahap pengembangan produk. Untuk mendesain produk berupa perangkat pembelajaran model debat aktif pada materi pemanasan global untuk siswa kelas XI SMA dilakukan dengan tahapan yaitu mendesain materi dan mendesain RPP. Penyusunan materi Perangkat pembelajaran diawali dengan silabus, dan kompetensi dasar. Berdasarkan silabus, kompetensi dasar pada materi pemanasan global yaitu : (3.12) Menganalisis gejala pemanasan global dan dampaknya bagi kehidupan dan lingkungan; (4.12) Menyajikan ide / gagasan pemecahan masalah gejala pemanasan global, dan dampaknya bagi kehidupan dan lingkungan. Kemudian dibuatlah lembar debat siswa sebagai panduan siswa dalam berdebat. Selanjutnya dibuatlah instrumen tes berupa soal essay sebagai instrumen ukur kemampuan siswa dan untuk kerangka desain awal dapat dilihat pada lampiran 2.

Setelah desain kerangka dan perangkat pembelajaran model debat aktif pada materi pemanasan global untuk siswa kelas XI SMA sudah dikembangkan, maka dilakukan tahap validasi desain. Tahap ini dilakukan untuk mengetahui kevalidan perangkat pembelajaran model debat aktif pada materi pemanasan global yang dikembangkan. Uji validitas untuk produk ini dilakukan oleh 3 judgement ahli (Dosen) yaitu IS (Ahli 1), DH (Ahli 2) dan (Guru/praktisi) YA (Ahli 3). Validasi dilakukan untuk mengukur kelayakan pengembangan perangkat pembelajaran. 
Aspek penyajian memiliki 3 butir penilaian yang mencerminkan penyajian dalam perangkat pembelajaran yang dikembangkan berupa kejelasan penyajian, kesesuaian tampilan perangkat pembelajaran, dan penyajian materi yang mana mendapat saran dari validator yaitu untuk menambahkan gambar supaya lebih menarik lagi. Berdasarkan hasil rata-rata uji validasi oleh ahli persentase penilaiannya yaitu 75,5\% yang berada pada kategori baik mengacu pada tabel 4.5.

Aspek isi memiliki 8 butir penilaian, dan butir penilaian kesesuaian penyajian materi dan kegiatan atau debat. Berdasarkan hasil rata-rata uji validasi oleh ahli dan praktisi persentase penilaian aspek isi yaitu $81,6 \%$ yang berada pada kategori sangat baik mengacu pada tabel 4.5.

Aspek bahasa memiliki 4 butir penilaian, dan berdasarkan hasil rata-rata uji validasi oleh judgement ahli dan praktisi persentase penilaian aspek isi yaitu 83,3\% yang berada pada kategori sangat baik mengacu pada tabel 4.5. Hasil tersebut dapat mencerminkan bahwa perangkat pembelajaran yang dikembangkan telah menggunakan bahasa yang baik, ketepatan struktur kalimat, konsistensi penggunaan istilah dan konsistensi penggunaan simbol yang baik.

Masukan atau saran validator digunakan sebagai acuan untuk melakukan revisi. Revisi yang dilakukan yaitu pada aspek penyajian dilakukan revisi berdasarkan saran dari valiadator. Revisi yang dilakukan pada aspek penyajian yaitu menambahkan gambar supaya perangkat pembelajaran menjadi lebih menarik lagi. Untuk aspek isi dan kebahasaan tidak dilakukan revisi karena berdasarkan hasil uji validitas aspek-aspek itu berada dalam kategori baik.. Kerangka perangkat pembelajaran yang sudah dikembangkan juga tidak mengalami revisi karena pada aspek penyajian mendapatkan persentase $75,5 \%$ dengan kategori baik dan tidak adanya saran dari validator sehingga kerangka akhir perangkat pembelajaran mengacu pada kerangka yang sudah dikembangkan.

Perangkat pembelajaran model debat aktif pada materi pemanasan global untuk siswa kelas XI SMA yang telah dinilai dan direvisi merupakan produk akhir dari penelitian ini dan merupakan desain teruji. Hal ini sesuai dengan pernyataan bahwa produk akhir dari penelitian research and development dengan tipe rancangan level 1 adalah desain teruji. Desain teruji merupakan desain dari hasil uji internal dan perbaikan dari judgement ahli (Kuliah, Tanah, and Ginanjar 2010).

Berdasarkan hasil total dari uji validitas aspek penyajian, isi dan bahasa, yang dilakukan oleh 3 judgement ahli maka dapat dikatakan bahwa perangkat pembelajaran model debat aktif pada materi pemanasan global untuk siswa kelas XI SMA yang sudah dikembangkan tergolong dalam kategori sangat baik/sangat valid dengan persentase rata-rata yaitu $80,13 \%$ dari $100 \%$ mengacu pada tabel 4.5. Hal ini berarti perangkat pembelajaran fisika yang dikembangkan sudah memenuhi aspek penyajian, isi dan bahasa sehingga, dapat disimpulkan bahwa perangkat pembelajaran model debat aktif pada materi pemanasan global yang sudah dikembangkan merupakan desain teruji. Penilaian akhir dari setiap validator adalah perangkat pembelajaran yang sudah dikembangkan sudah layak akan tetapi perlu adanya revisi.

Penelitian ini relevan dengan penelitian yang berjudul "Pengembangan Perangkat Pembelajaran Fisika Menggunakan Model Guided Inquiry yang Dilengkapi Penilaian Portofolio pada Materi Gerak Melingkar" yang mana hasil dari penelitian ini dinyatakan sangat valid dan bahkan lembar penilaian disimpulkan sangat valid tanpa revisi (Perpustakaan and Yogyakarta n.d.). Pengembangan prangkat ini pun dinyatakan sangat praktis dan efektif oleh validator. Meskipun pada model dan materi yang digunakan berbeda namu perangkat pembelajaran pada penelitian ini dapat menjadi acuan.

Saat melakukan pengembangan produk terdapat beberapa kendala. Kendala-kendala yang dihadapai saat mengembangkan adalah masih terbatasnya materi pada buku cetak disekolah sedangkan cakupan materi ini terus berkembang seiring dengan berkembangnya zaman dan kasus permasalahan yang timbul juga semakin beragam untuk dibahas oleh forum kelas. Adapun kelebihan produk akhir yang sudah dikembangkan dengan produk awal yang didapat yaitu perangkat pembelajaran yang dikembangkan menggunakan langkah-langkah model pembelajaran debat aktif yang dapat melatih kemampuan berpikir kritis dan berargumentasi siswa, instrumen tes dan penilaian yang sesuai dengan kemampuan yang akan diukur dan terdapat kunci jawaban serta daftar pustaka. 


\section{SIMPULAN DAN SARAN}

\subsection{Kesimpulan}

Berdasarkan analisis data dan pembahasan dalam penelitian pengembangan perangkat pembelajaran model debat aktif pada materi pemanasan global untuk siswa kelas XI SMA diperoleh kesimpulan sebagai berikut : (1) Proses pembuatan perangkat pembelajaran ini dimulai dari mencari potensi dan masalah kemudian dilakukan studi literatur diperoleh bahwa perangkat pembelajaran dapat dikembangkan sebagai media untuk belajar aktif dan dapat mengarahkan peserta didik memecahkan persoalan fisika melalui langkah-langkah model debat aktif dengan materi pemanasan global untuk siswa kelas XI SMA, selanjutnya dibuatlah desain perangkat pembelajaran yang kemudian dilakukan validasi oleh 3 orang ahli dimana hasil dari validasi tersebut di analisis datanya dan dilakukanlah perbaikan desain berasarkan saran-saran dari para validator tersebut. (2) Berdasarkan uji internal oleh judgement ahli, perangkat pembelajaran yang dikembangkan termasuk dalam kategori layak dan merupakan desain teruji karena mendapatkan respon positif dengan presentase untuk aspek penyajian yaitu 75,5\% dengan kategori valid, untuk aspek isi mendapat presentase $81,6 \%$ dengan kategori sangat valid, dan untuk aspek kebahasaan 83,3\% dengan kategori sangat valid. Dengan rata-rata peresentase uji validitas untuk keseluruhan aspek sebesar $80,13 \%$, maka perangkat pembelajaran yang dikembangkan secara keseluruhan berada pada kategori sangat valid.

\subsection{Saran}

Berdasarkan keterbatasan produk yang dikembangkan maka saran-saran untuk penelitian ini adalah sebagai berikut: (1) Perangkat pembelajaran yang dihasilkan belum melalui uji coba lapangan dikarenakan sedang masa pandemi, untuk itu perlunya dilakukan penelitian lanjutan yaitu perangkat pembelajaran ini di uji cobakan kepada siswa dikelas. (2) Untuk pengembangan selanjutnya diharapkan bisa memilih topik materi yang lebih terbaru dan bervariasi pada lembar debat siswa supaya permasalahan yang diangkat dalam debat lebih bisa menyesuaikan dengan perkembangan zaman kemudian topik permasalahan tersebut sedang hangat diperbincangkan dimedia massa.

\section{UCAPAN TERIMA KASIH}

Penulis mengucapkan terimakasih kepada validator ahli yaitu Dedy Hamdani, M.Si dan Dr Iwan Setiawan, M.Sc serta Responden guru SMAN 7 Kota Bengkulu yang sudah bersedia untuk membatu pengisian angket pengembangan perangkat pembelajaran model debat aktif pada materi pemanasan global untuk siswa kelas XI SMA.

\section{DAFTAR PUSTAKA}

(Tata Sutabri, 2012:38). 2011. "BAB II Landasan Teori.” Google.com.

Bettelheim, Bruno. 1980. "Scanned by CamScanner كمزارى." A psicanalise dos contos de fadas. Tradução Arlene Caetano: 466.

Centre, Physical Sciences. 2005. 6 Physical Sciences Educational Reviews.

Chodijah, Siti, Ahmad Fauzi, and Ratna Wulan. 2012. "Pengembangan Perangkat Pembelajaran Fisika Menggunakan Model Guided Inquiryyang Dilengkapi Penilaian Portofolio Pada Materi Gerak Melingkar.” Jurnal Penelitian Pembelajaran Fisika 1: 1-19.

Dan, Konsep, Komunikasi Ilmiah, Siswa Pada, and Mata Pelajaran. 2014. "Penerapan Model Pembelajaran Cooperative Problem Solving Untuk Meningkatkan Kemampuan Pemahaman Konsep Dan Komunikasi Ilmiah Siswa Pada Mata Pelajaran Fisika.” UPEJ (Unnes Physics Education Journal) 3(2).

Diani, Rahma. 2015. "Pengembangan Perangkat Pembelajaran Fisika Berbasis Pendidikan Karakter Dengan Model Problem Based Instruction.” Jurnal Ilmiah Pendidikan Fisika Al-Biruni 4(2): 243.

Fauziyah, Salamah. 2019. "Pembelajaran Model Inquiry Training Berbantu Pelajaran Pendidikan Agama Islam Di Kelas Xi Sma Negeri 7 Cirebon.” 4(1): 101-14. 
Firdauzi, Fadlilah Siti, Rahma Widiantie, and Handayani Handayani. 2019. "Penerapan Model Pembelajaran Problem Based Learning Dipadu Metode Debat Terhadap Kemampuan Berargumentasi." Quagga : Jurnal Pendidikan dan Biologi 11(1): 51.

Herayanti, Lovy, Muhammad Fuaddunnazmi, and Habibi Habibi. 2017. "Pengembangan Perangkat Pembelajaran Fisika Berbasis Moodle.” Jurnal Pendidikan Fisika dan Teknologi 3(2): 197.

Kuliah, Mata, Pemindahan Tanah, and Anton Ginanjar. 2010. "No Title." pengembangan media pembelajaran modul interaktif mata kuliah pemindahan tanah mekanik.

Nurdyansyah, and Eni Fariyatul Fahyuni. 2016. Nizmania Learning Center Inovasi Model.

Perpustakaan, U P T, and I S I Yogyakarta. "UPT Perpustakaan ISI Yogyakarta» Modul Kewirausahaan Untuk Progra... Http://Lib.Isi.Ac.Id/Buku-Terbaru/Modul-KewirausahaanUntuk-Program-Stra...” : 4-5.

Purwono, Joni, Sri Yutmini, and Sri Anitah. 2014. "PENGGUNAAN MEDIA AUDIO-VISUAL PADA MATA PELAJARAN ILMU PENGETAHUAN ALAM DI SEKOLAH MENENGAH PERTAMA NEGERI 1." Jurnal Teknologi Pendidikan Dan Pembelajaran.

Yoki. 2010. "BAB II LANDASAN TEORI 2.1 Umum.” 222.124.203.59.

Zahara, Laxmi et al. 2019. "Pengaruh Metode Pembelajaran Debat Dan Diskusi Terhadap Prestasi Belajar Ditinjau Dari Kemampuan Berpikir Kritis Mahasiswa Kemampuan Berpikir Kritis Dan Kemampuan Berkomunikasi .” Kappa Journal 3(2): 118-25. 